\title{
ANALISIS PENGARUH KEBIJAKAN ZONASI TERHADAP MOTIVASI DAN PRESTASI BELAJAR SISWA SMP DENGAN REGRESI LINEAR
}

\author{
Dharma Bagus Pratama Putra*1, Anita Andriani ${ }^{2}$ \\ ${ }^{1,2}$ Universitas Hasyim Asy’ari \\ dharmabaguspp@gmail.com*1, anitaandriani@unhasy.ac.id² \\ *Corresponding Author
}

Received 10 September 2020; revised 12 November 2020; accepted 17 November 2020.

\begin{abstract}
ABSTRAK
Penelitian ini bertujuan untuk menyelidiki pengaruh kebijakan zonasi terhadap motivasi dan prestasi belajar siswa. Subyek yang dipilih dalam penelitian ini adalah siswa kelas IX SMPN di kecamatan Pare. Penelitian ini merupakan penelitian kuantitatif. Teknik yang digunakan dalam pengumpulan data adalah angket yang terdiri dari 50 pertanyaan, 30 tentang persepsi zonasi, dan 20 lainnya tentang motivasi belajar. Teknik analisis data menggunakan metode regresi linear dengan variabel bebas adalah pemahaman zonasi sedangkan variabel terikatnya yaitu motivasi dan prestasi belajar. Hasil analisis data didapatkan bahwa variabel zonasi hanya memberikan pengaruh sebanyak 3.39\% terhadap motivasi belajar dan mempengaruhi prestasi belajar sebesar 3.99\%, sisanya dipengaruhi oleh variabel lain. Uji korelasi antara variabel zonasi dan motivasi menghasilkan $p$-value $=0.102$ yang berarti lebih besar daripada $\alpha=0.05$. Dari hasil tersebut disimpulkan bahwa zonasi tidak memperikan pengaruh yang signifikan terhadap motivasi belajar. Demikian juga uji korelasi antara variabel zonasi dan prestasi belajar didapatkan $p-$ value $=$ 0.5776 yang lebih besar daripada $\alpha=0.05$ sehingga variabel zonasi tidak memberikan pengaruh yang signifikan pada variabel prestasi belajar siswa.
\end{abstract}

Kata kunci: motivasi, prestasi belajar, regresi linear, zonasi.

\begin{abstract}
The purpose of this research to investigate the impact of zoning policies on students motivation and learning achievement. The subjects that used in this study are IX grade students of State Junior High School in Pare sub-area. This sort of exploration is quantitative examination. The data collection technique used a questionnaire consisting of 50 questions, 30 about the perception of zoning and 20 others about learning motivation. The information analysis procedure utilized linear regression method. The after effects of information analysis showed that the zoning
\end{abstract}


variable only had an effect of 3.39\% on learning motivation and 3.99\% on learning achievement, the rest was influenced by other variables. The correlation test between zoning and motivation variables resulted in a $p$-value $=0.102$ which was greater than $\alpha=0.05$, so it could be concluded that zoning did not have a significant effect on learning motivation. Likewise, the correlation test between zoning variables and learning achievement obtained $p$-value = 0.5776 which is greater than $\alpha=0.05$ so that the zoning variable does not have a significant effect on students learning achievement variables.

Keywords: motivation, learning achievement, linear regression, zoning.

\section{PENDAHULUAN}

Berdasarkan Permendikbud RI Nomor 51 tahun 2018 tentang penerimaan peserta didik baru, setiap sekolah negeri di bawah naungan kemendikbud wajib menerapkan konsep zonasi pada Penerimaan Peserta Didik Baru (PPDB) (Kemdikbud, 2018). Permendikbud tersebut lebih lanjut menjelaskan bahwa ada tiga jalur utama PPDB yaitu zonasi minimal sebesar 90\%, prestasi maksimal 5\%, dan pindah tugas orang tua sebesar 5\%. Zonasi yang dimaksud adalah PPDB harus memprioritaskan siswa yang masuk pada zona yang ditetapkan oleh pejabat daerah yang berwenang. Menteri Pendidikan Indonesia mengatakan bahwa zonasi merupakan salah satu cara untuk mengurangi ketimpangan kualitas pendidikan pada sistem sekolah (TIM, 2018).

Namun kebijakan sistem zonasi mendapatkan pro dan kontra dari masyarakat. Berdasarkan wawancara dengan 15 wali murid kelas IX di salah satu SMPN Kecamatan Pare, 8 diantaranya tidak setuju dengan sistem zonasi. Berbagai alasan dikemukakan sebagai bentuk penolakan. 4 diantara wali murid tersebut mengatakan bahwa anaknya menjadi jarang belajar karena rumahnya dekat dengan sekolah favorit. Ini merupakan salah satu indikator menurunnya motivasi belajar siswa. Fakta ini didukung dengan hasil observasi lapangan di salah satu lembaga bimbingan belajar (bimbel) yang cukup besar di Pare. Sebelum adanya peraturan zonasi, siswa kelas IX dari SMPN di bimbel ada 5 kelas dengan rata-rata setiap kelas berisi 25 siswa. Sekarang, siswa SMPN di bimbel tersebut hanya ada 1 kelas.

Motivasi adalah kondisi yang memberikan dorongan untuk bertindak mencapai tujuan (Soemanto, 2006). Jika tindakan tersebut berupa kegiatan belajar, maka motivasi belajar adalah suatu kondisi yang mendorong individu untuk 
melakukan kegiatan belajar. Makmun (2009) memberikan deskripsi bahwa indikator motivasi belajar secara operasional ada 8. Indikator tersebut antara lain: (1) durasi waktu belajar, yaitu seberapa lama kemampuan dalam menggunakan waktu belajar; (2) frekuensi belajar, yaitu berapa sering belajar seseorang pada waktu tertentu; (3) konsistensi belajar, yaitu seberapa teguh seseorang terhadap sasaran dalam belajar; (4) kegigihan dan kapabilitas dalam mengatasi problematika untuk meraih target belajar; (5) Dedikasi baik uang, tenaga, dan pikiran dalam upaya mendapatkan target belajar; (6) tekad belajar, yaitu rancangan dan tujuan yang ingin diraih pada kegiatan belajar; (7) tingkat kualifikasi prestasi dalam belajar, yaitu prestasi yang dicapai dalam kegiatan belajar; (8) pandangan dan sikap seseorang dalam tujuan belajar, maksudnya positif atau negatif sikap seseorang terhadap pembelajaran. Slameto (2003) mengungkapkan bahwa prestasi belajar dipengaruhi oleh motivasi belajar.

Winkel (1984) berpendapat prestasi merupakan salah satu tanda kesuksesan dari sebuah usaha yang telah dikerjakan. Apabila usaha yang dilakukan adalah kegiatan belajar maka prestasi belajar adalah suatu bukti keberhasilan pada proses kegiatan belajar. Prestasi belajar pada penelitian ini adalah kenaikan hasil belajar, yang didapatkan dari selisih nilai rata-rata rapor kelas IX dan kelas VII. Banyak cara yang dapat ditempuh pendidik untuk meningkatkan prestasi belajar misalnya dengan membuat modul pembelajaran, menganalisis kesalahan siswa dalam mengerjakan ujian dan sebagainya (Putra dkk, 2018a; Putra dkk, 2018b). Slameto (2003) menyebutkan bahwa kurikulum dan kebijakan sekolah adalah faktor lain yang memiliki pengaruh pada prestasi belajar. Hasil penelitian Wulandari (2018) juga menunjukkan pengaruh yang signifikan dari sistem zonasi terhadap prestasi belajar siswa SMPN.

\section{METODE PENELITIAN}

Jenis penelitian yang digunakan adalah penelitian kuantitatif. Penelitian ini melihat seberapa besar dampak dari kebijakan zonasi pada motivasi dan prestasi siswa. Penelitian ini dilakukan di Kecamatan Pare, Kabupaten Kediri. Populasi adalah siswa SMPN kelas IX tahun akademik 2019/2020 di Kec. Pare, Kab. Kediri, Provinsi Jawa Timur. Siswa kelas IX dipilih karena mereka yang akan 
merasakan dampak zonasi dan lebih paham pengertian zonasi daripada siswa kelas bawahnya. Berdasarkan data Dinas Pendidikan Kabupaten Kediri terdapat 3669 siswa di SMPN Kecamatan Pare. Jumlah sampel penelitian adalah 80 siswa dan teknik pengambilan sampel menggunan random sampling. Setiap sekolahan akan diambil 20 siswa secara acak, sehingga semua SMPN di Kecamatan Pare terwakili.

Instrumen penelitian yang dipakai adalah kuisioner online (dengan google form). Kuisioner terdiri dari 50 pertanyaan yang dibagi menjadi dua kriteria, yaitu persepsi terhadap zonasi terdiri dari 30 pertanyaan, dan motivasi belajar terdiri dari 20 pertanyaan. Kuisioner dibuat menggunakan skala likert dan terdiri dari empat alternatif jawaban yaitu sangat setuju (SS), setuju (S), kurang setuju (KS), dan tidak setuju (TS). Nilai untuk jawaban dengan pertanyaan positif adalah sangat setuju $(\mathrm{SS})=4$, setuju $(\mathrm{S})=3$, kurang setuju $(\mathrm{KS})=2$, tidak setuju $(\mathrm{TS})=$ 1. Sebaliknya untuk pertanyaan negatif nilai masing-masing jawaban adalah sangat setuju $(\mathrm{SS})=1$, setuju $(\mathrm{S})=2$, kurang setuju $(\mathrm{KS})=3$, tidak setuju $(\mathrm{TS})=$ 4.

Analisis data menggunakan metode regresi linear dengan bantuan software R untuk menyelidiki hubungan antar variabel (Andriani, 2017). Regresi linier digunakan karena penelitian ini tidak hanya melihat seberapa erat hubungan antar variabel, tetapi juga melihat ada tidaknya hubungan antara variabel bebas dan variabel terikat. Variabel yang terdapat di penelitian ini ada dua jenis yaitu variabel terikat (dependent) disimbolkan dengan $Y$ dan variabel bebas (independent) disimbolkan dengan $X$. Variabel bebas (independent) yaitu variabel yang menjadi penyebab atau memberi pengaruh kepada variabel terikat. Variabel $X$ pada penelitian ini adalah persepsi siswa mengenai sistem zonasi, sedangkan variable $Y$ penelitian ada dua, yaitu motivasi belajar siswa $\left(Y_{1}\right)$ dan prestasi belajar siswa $\left(Y_{2}\right)$.

\section{HASIL DAN PEMBAHASAN}

Pengambilan data dilakukan dengan kuisioner online. Gambar 1 merupakan data statistik deskriptif yang didapat dari kuisioner. 
$>$ summary (minatpersepsi)

\begin{tabular}{|c|c|c|c|c|c|c|c|}
\hline \multicolumn{2}{|c|}{ Prestasi } & \multicolumn{2}{|c|}{ Minat } & \multicolumn{2}{|c|}{ Persepsi } & \multicolumn{2}{|c|}{ Jarak } \\
\hline Min. & $:-2.080$ & Min. & : 70.00 & Min. & $: 46.00$ & Min. & $: 0.160$ \\
\hline lst & $: 0.595$ & lst Qu & : 82.00 & lst Qu & .54 .75 & lst Qu & $: 1$. \\
\hline edian & $: 2.000$ & Median & : 86.00 & Median & $: 59.00$ & Median & $: 2.3$ \\
\hline$a n$ & : 1.855 & Mean & $: 86.55$ & Mean & $: 58.83$ & Mean & 4. \\
\hline $\mathrm{rd}$ & $: 2.82$ & $3 \mathrm{rd} Q u$ & : 91.00 & $3 \mathrm{rd} Q$ & $: 62.00$ & $3 \mathrm{rd} Q u$ & 7. \\
\hline ax. & $: 7.21$ & Max. & : 105.00 & Max. & $: 74.00$ & Max. & $: 27$. \\
\hline
\end{tabular}

Gambar 1. Statistik Deskriptif dari Data

Kuisioner terdiri dari 50 pertanyaan yang dibagi menjadi dua kriteria, persepsi terhadap zonasi terdiri dari 23 pertanyaan dan motivasi belajar terdiri dari 27 pertanyaan. Persepsi yang dimaksud adalah pemahaman siswa mengenai sistem zonasi. Rata-rata dari variabel persepsi adalah 58.83 dari nilai maksimal 92, artinya sebagaian besar siswa cukup memahami tentang PPDB sistem zonasi. Motivasi belajar memiliki rata-rata 86.55 dari nilai maksimal 108. Variabel prestasi didapatkan dari selisih rata-rata nilai rapor kelas IX dan Kelas VII. Nilai negatif artinya terjadi penurunan pada nilai rata-rata rapor. Jumlah data sampel cukup besar sehingga data diasumsikan normal dan tidak dilakukan uji asumsi klasik. Kemudian setiap variabel akan diuji dengan metode regresi linear.

Hasil uji variabel persepsi zonasi dan motivasi belajar siswa ditunjukan di Gambar 2.

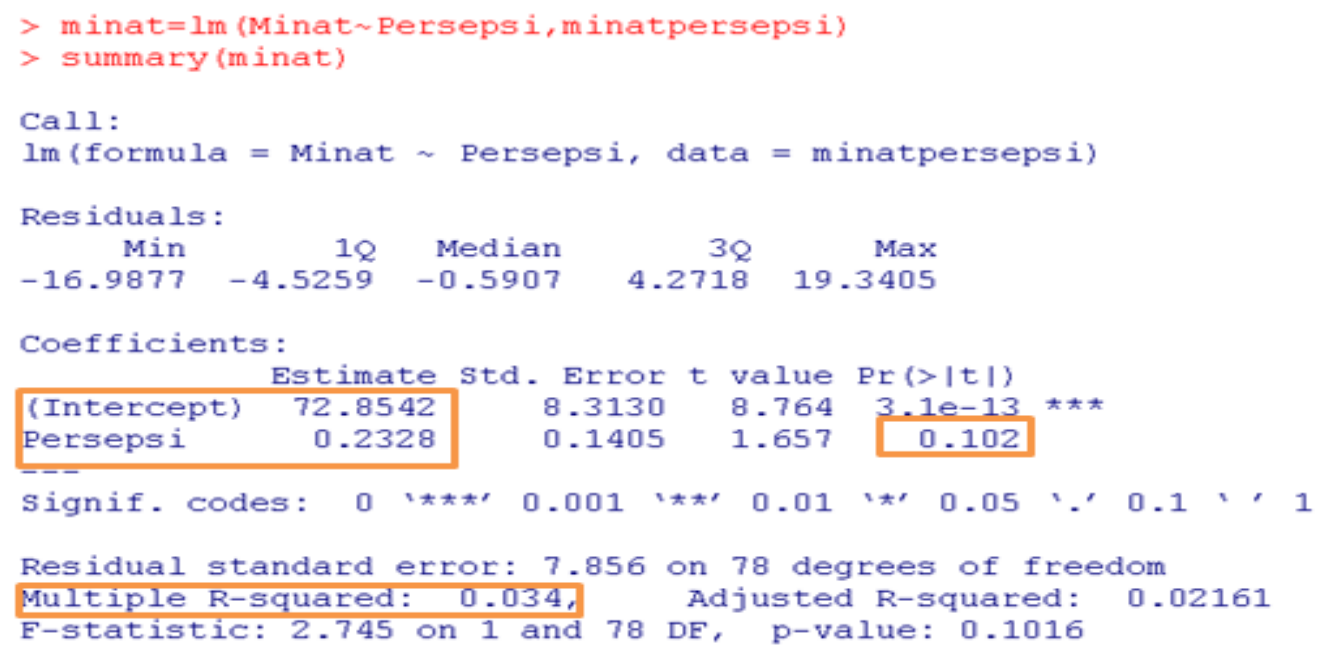

Gambar 2. Hasil Uji Regresi Linear Variabel Zonasi dengan Motivasi Belajar

Nilai alpha $(\alpha)$ yang digunakan adalah 5\%. Berdasarkan analisis data didapatkan bahwa koefisien dari zonasi $(x)$ sebesar 0.2328 sehingga didapatkan 
persamaan regresi $Y_{1}=72.854+0.2328 x$. Didapatkan nilai dari $p$-value yaitu 0.102. Karena nilai dari $p$-value lebih dari nilai $\alpha=0.05$ maka secara teori variabel zonasi tidak memiliki dampak yang signifikan pada variabel motivasi belajar.Ini juga didukung dengan nilai $R$-squared sebesar 3,4\% artinya variabel Persepsi (zonasi) hanya mampu menjelaskan 3,4\% keragaman variabel Motivasi, sisanya dijelaskan oleh variabel yang lain.

Untuk memeriksa lebih jauh tentang hubungan dua variabel, digunakan uji korelasi dengan $\alpha=5 \%$ dengan dibuat hipotesis H0: tidak ada hubungan antar dua variabel, dan H1: ada hubungan antar dua variabel. Gambar 3 menyajikan data hasil uji korelasi.

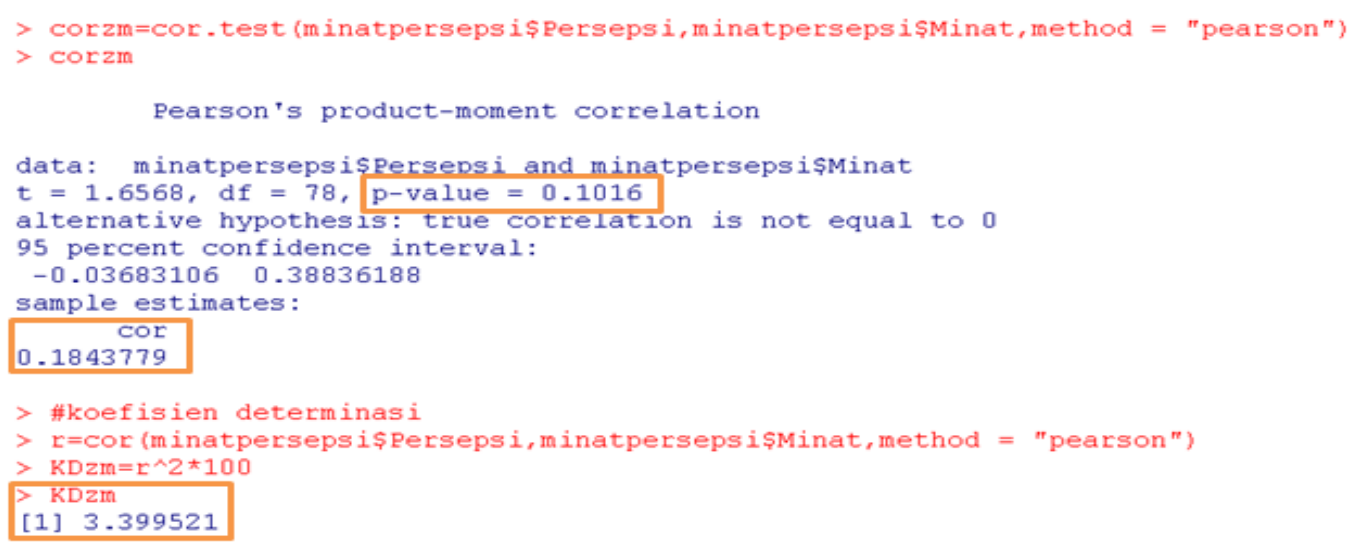

Gambar 3. Hasil Uji Korelasi Zonasi dengan Motivasi Belajar

Berdasarkan Gambar 3 terlihat bahwa variabel motivasi dengan variabel persepsi zonasi memiliki keeratan sebesar 0.184. Nilai $p$-value yang didapatkan adalah 0.1016. Karena $p$-value $>0.05$ artinya H0 tidak ditolak, atau terima H0. Nilai $R$-Squared yang didapatkan adalah sebesar 3.39 artinya variabel zonasi terhadap keragaman variabel motivasi hanya mampu dijelaskan sebesar 3.39\%. Hasil tersebut juga sesuai dengan hasil yang diperoleh pada analisa sebelumnya.

Langkah dalam uji persepsi terhadap prestasi sama dengan uji sebelumnya. Pertama kita menggunakan uji regresi linear sederhana kemudian dilanjutkan dengan uji korelasi. Gambar 4 adalah hasil pengujian dengan metode regresi linear sederhana. 


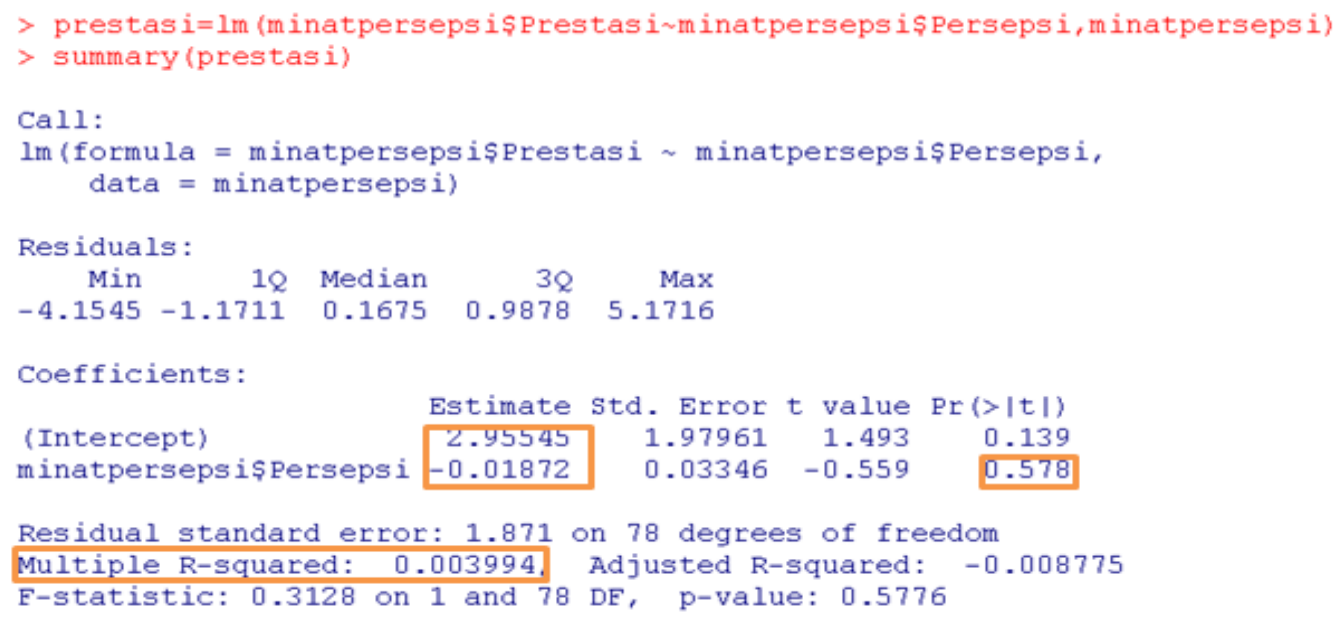

Gambar 4. Hasil Uji Regresi Linear Variabel Zonasi dengan Prestasi Belajar

Dari data pada Gambar 4, didapatkan koefisien variabel $x$ adalah -0.019 sehingga persamaan regresi linearnya adalah $Y_{2}=2.955-0.019 x$. Nilai dari $p$-value adalah 0.578 yang lebih besar dari $\alpha=0.05$. Sehingga secara teori pengaruh variabel persepsi zonasi tidak signifikan terhadap prestasi belajar siswa. R-squared sebesar $0.39 \%$ artinya variabel persepsi (zonasi) mampu menjelaskan $0.39 \%$ keragaman variabel prestasi, sisanya dijelaskan oleh variabel yang lain.

Selanjutnya dilakukan uji korelasi. Hipotesis yang digunakan ada 2, yaitu H0: tidak terdapat hubungan antar dua variabel, H1: terdapat hubungan antar dua variabel. Taraf keberartian yang digunakan adalah 5\%. Gambar 5 merupakan hasil analisis data

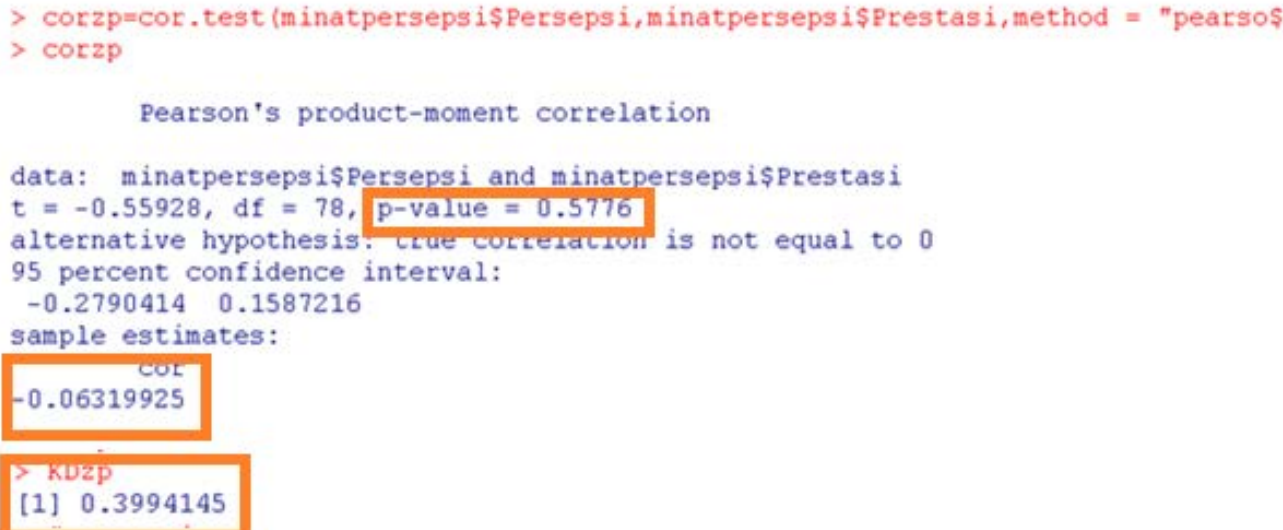

Gambar 5. Hasil Uji Korelasi Zonasi dengan Prestasi Belajar 
Berdasarkan hasil pada Gambar 5, terlihat bahwa antara variabel prestasi dengan variabel persepsi, keeratannya adalah sebesar -0.0632 . Nilai $p$-value yang didapatkan adalah $0.5776>0.05$ artinya H0 tidak ditolak, atau terima H0. Nilai R-Squared adalah sebesar 3.99 artinya, variabel persepsi mampu menjelaskan keragaman variabel motivasi sebesar 3.99\%.

\section{SIMPULAN}

Berdasarkan hasil penelitian pengaruh sistem zonasi terhadap motivasi dan prestasi belajar siswa SMPN di Kecamatan Pare dapat disimpulkan variabel persepsi hanya mampu memberikan kontribusi sebesar 3.39\% terhadap motivasi belajar siswa SMPN di Kecamatan Pare. Hasil analisis menunjukkan bahwa koefisien parameter dari variabel persepsi adalah sebesar 0.2328 dan nilai $p$-valuenya adalah 0.102 . Nilai $p$-value yang lebih besar dari alpha ini menunjukkan bahwa tidak ada pengaruh yang signifikan dari variabel persepsi terhadap variabel motivasi belajar. Dengan demikian, sistem zonasi tidak berpengaruh terhadap motivasi belajar siswa SMPN di Kecamatan Pare. Kemampuan menjelaskan keragaman variabel persepsi terhadap prestasi belajar siswa SMPN di Kecamatan Pare hanya sebesar 3.99\%, sedangkan koefisien parameter dari variabel persepsi adalah sebesar -0.019 dengan $p$-value sebesar 0.5776. Nilai $p$ - value yang lebih besar dari alpha menunjukkan bahwa tidak ada pengaruh yang signifikan dari variabel persepsi terhadap prestasi belajar. Dengan demikian, sistem zonasi tidak berpengaruh terhadap prestasi belajar siswa SMPN di Kecamatan Pare.

\section{UCAPAN TERIMA KASIH}

Penulis menyampaikan ucapan terima kasih kepada DRPM Kemenristek Dikti dalam pembiayaan skim Penelitian Dosen Pemula tahun pelaksanaan 2020.

\section{DAFTAR PUSTAKA}

Andriani, A. (2017). Pemanfaatan software $\mathrm{R}$ untuk analisis regresi linear. Inovate: Jurnal Ilmiah Inovasi Teknologi Informasi, 2(2).

Kemdikbud. (2018). Permendikbud nomor 51 tahun 2018 tentang sistem penerimaan peserta didik baru. Retrieved September 5, 2020, from JDIH Kementerian

Pendidikan

dan

Kebudayaan: 
https://jdih.kemdikbud.go.id/arsip/PERMENDIKBUD\%20NOMOR\%205 1\%20TAHUN\%202018.pdf

Makmun, A. S. (2009). Psikologi kepribadian. Bandung: PT Remaja Rosdakarya.

Putra, D. B. P., Lazulfa, I., \& Mufarrihah, I. (2018a). Identifikasi kesalahan mahasiswa teknik informatika dalam menyelesaikan soal statistika. MUST: Journal of Mathematics Education, Science and Technology, 3(2), 153151. http://dx.doi.org/10.30651/must.v3i2.1876

Putra, D. B. P., Lazulfa, I., \& Mufarrihah, I. (2018b). Pengembangan modul berbasis kompetensi pada mata kuliah statistika mahasiswa jurusan teknik informatika Universitas Hasyim Asy’ari. Jurnal Kajian Pembelajaran Matematika, 2(2), 57-63.

Slameto. (2003). Belajar dan faktor-faktor yang mempengaruhinya. Jakarta: Rineka Cipta

Soemanto, W. (2006). Psikologi pendidikan: landasan kerja pemimpin pendidikan (cetakan ke 5). Jakarta: Rineka Cipta.

TIM. (2018). Semua bisa sekolah! zonasi untuk pemerataan yang berkualitas. Retrieved September 5, 2020, from Kementerian Komunikasi dan Informatika Republik Indonesia: https://kominfo.go.id/content/detail/13689/semua-bisa-sekolah-zonasiuntuk-pemerataan-yang-berkualitas/0/artikel_gpr

Winkel. (1984). Psikologi pendidikan dan evaluasi belajar. Jakarta: Gramedia.

Wulandari, D. (2018). Pengaruh penerimaan peserta didik baru melalui sistem zonasi terhadap prestasi belajar siswa kelas VII di SMPN 1 Labuhan Ratu Lampung Timur tahun pelajaran 2017/2018. [Skripsi] Lampung: Universitas Lampung. 